Article

\title{
Adoption of Multiple Sustainable Manure Treatment Technologies by Pig Farmers in Rural China: A Case Study of Poyang Lake Region
}

\author{
Jingyuan Cai ${ }^{1}$, Liguo Zhang ${ }^{2, *}$, Jing Tang ${ }^{2}$ and Dan Pan ${ }^{2,3, * \mathbb{D}}$ \\ 1 School of Accounting Shanghai National Accounting Institute, Shanghai 201702, China; \\ daisy_cai@outlook.com \\ 2 School of Economics, Jiangxi University of Finance and Economics, Nanchang 330013, China; \\ tjing_0318@163.com \\ 3 Jiangxi Provincial Condition Research Center, Nanchang 330077, China \\ * Correspondence: njlgzhang@163.com (L.Z.); pandan@jxufe.edu.cn (D.P.); Tel.: +86-791-8381-6042
}

Received: 26 June 2019; Accepted: 13 November 2019; Published: 16 November 2019

\begin{abstract}
The adoption of sustainable manure treatment technologies (SMTTs) in livestock production helps to reduce agricultural contamination. As such, understanding what determines farmers' adoption of SMTTs is an essential prerequisite for the administrative handling of livestock pollution. Applying a multivariate probit model on a cross-sectional data set of 686 pig farmers in Poyang Lake Region in China, this study discovered that two key factors influencing farmers' decisions to adopt multiple SMTTs are off-farm labor and environmental awareness. In other words, households with a higher share of off-farm labor are less likely to adopt SMTTs. Farmers with higher environmental awareness are more likely to adopt SMTTs. The results also revealed that because of the inappropriateness of government subsidy and insufficient technical training, the impact of Chinese government subsidy on the adoption of biogas technology is negligible, but the subsidy on composting greatly helps to promote the adoption of composting technology. We also found a substitution effect and complementary effects between different SMTTs. These findings can improve policymakers' understanding of farmers' joint adoption decisions. It also helps policymakers to optimize subsidy strategies to encourage farmers' adoption of SMTTs in rural China.
\end{abstract}

Keywords: pig production; manure management; multivariate probit model; Poyang Lake region

\section{Introduction}

With the increasingly rapid industrialization and urbanization progress, as well as the growing demand for livestock products, livestock production in China has developed rapidly in recent years [1]. The gross output value of livestock production in 2018 in China is RMB 28,697 billion ( $\$ 4159$ billion), which is 137 times more than the value in 1978. Currently, China is the world's largest producer of livestock products [2]. The continued increase in livestock production has generated a large amount of manure. It is estimated that the Chinese livestock industry produces approximately 3.8 billion tons of manure each year [3]. Theoretically, if treated appropriately, this amount of manure can produce 3.68 million tons of organic fertilizers with a total value of RMB 262 billion ( $\$ 38$ billion) annually [3].

To stimulate sustainable manure management, a series of policies, including subsidy policies, rules, and regulations, are enforced in China [4,5]. For example, the Chinese government has provided financial subsidies to induce farmers to apply biogas technology for manure treatment since 2000. It is reported that the total biogas subsidy for manure treatment has reached nearly RMB 500 billion ( $\$ 72.5$ billion) in 2018 [6]. In 2014, The Ministry of Agriculture and the Ministry of Finance started the "Sustainable Manure Treatment" program, and by 2018, the Chinese government had invested RMB 430 billion ( $\$ 62.3$ billion) to 
promote this program. In addition, some regulations, such as "Prevention and Treatment on Pollution from Livestock Cultivation", stated that farms must treat manure in a sustainable way. In some provinces, farmers will pay a pollution fee if they do not treat manure in a sustainable way; the level of pollution fees ranged from $30 \mathrm{RMB} /$ head/year to $120 \mathrm{RMB} /$ head/year in pig production [7].

Despite these massive initiatives to encourage farmers to treat manure in a sustainable way, farmers' adoption rate of sustainable manure treatment technologies (SMTTs) remains low [7]. It is reported that $40 \%$ of manure in China is not effectively treated and utilized and over $20 \%$ of manure is being directly discarded into rivers or lands without appropriate processing [3]. Unsustainable treated manure will cause great harm to the air, land, water systems, and human health [8]. As such, strategic management of livestock manure is an important approach to reduce GHG emissions and to protect the environment [3]. Understanding the main influencing factors that impede or facilitate farmers' adoption of SMTTs is an essential prerequisite toward the sustainability of livestock production in the rural areas of both the developed and developing countries.

Most existing studies have treated farmers' adoption of SMTTs as separate decisions, focusing on the adoption of only one or two isolated types of SMTTs independently, such as returning to the field [2,9], producing biogas [10,11], composting [12], sale [7], and arbitrary discard [13]. Limited attention has been given to the adoption of multiple types of SMTTs. However, as the benefits, costs, and constraints associated with different manure treatment technologies are in great variety, farmers may adopt a bundle of manure treatment technologies rather than a single technology to maximize their expected utility [14]. For example, Zheng et al. [15] found that farmers often simultaneously adopt a bundle of SMTTs, and different SMTTs may be closely related, either as complements or as substitutes. Pan et al. [7] also highlighted that the impact of SMTTs on manure pollution reduction depends on whether they are adopted independently or as a package. Hence, analyses without considering interdependence among different SMTTs may get biased estimates of the impact of various factors on the decision of SMTTs adopting.

Therefore, this study aims to fill this gap by employing a multivariate probit model (MVP) to jointly analyze the driving forces that facilitate or impede the probability of farmers' simultaneous adoption of multiple SMTTs. Our study is based on first-hand collected data of 686 pig farmers in the Poyang Lake Region (PLR) of China, a region located in one of the largest freshwater lakes in China and the biggest ecological wetland in Asia.

Pig farmers are selected for this study because pig manure management is the main challenge of sustainable manure management in China. Pigs are the main slaughtered livestock in China. For example, the number of slaughtered pigs was 694 million in China in 2018, accounting for 55\% of the world's total slaughtered pigs [16]. Pig manure accounts for more than $60 \%$ of all manure from livestock production in China. As such, understanding the adoption of SMTTs by pig farmers is important for livestock manure management.

The remaining part of the paper proceeds as follows: Section 2 provides detailed information on the data and statistical model. Section 3 reports the estimation results of the multivariate probit model. The final section gives conclusions.

\section{Materials and Methods}

\subsection{Study Site}

This paper selected the Poyang Lake Region (PLR) in Jiangxi Province as the study site (see Figure 1). Located in Poyang Lake, one of the largest freshwater lakes in China and the biggest ecological wetland in Asia, PLR plays an important role in safeguarding the ecological environment and protecting biodiversity [17]. However, in recent years, pollution from livestock production has caused accelerated environmental deterioration in this region, such as eutrophication, water quality decline, and biodiversity losses [18]. Advancing farmers' adoption of SMTTs in this region is a significant way towards environmental sustainability. 


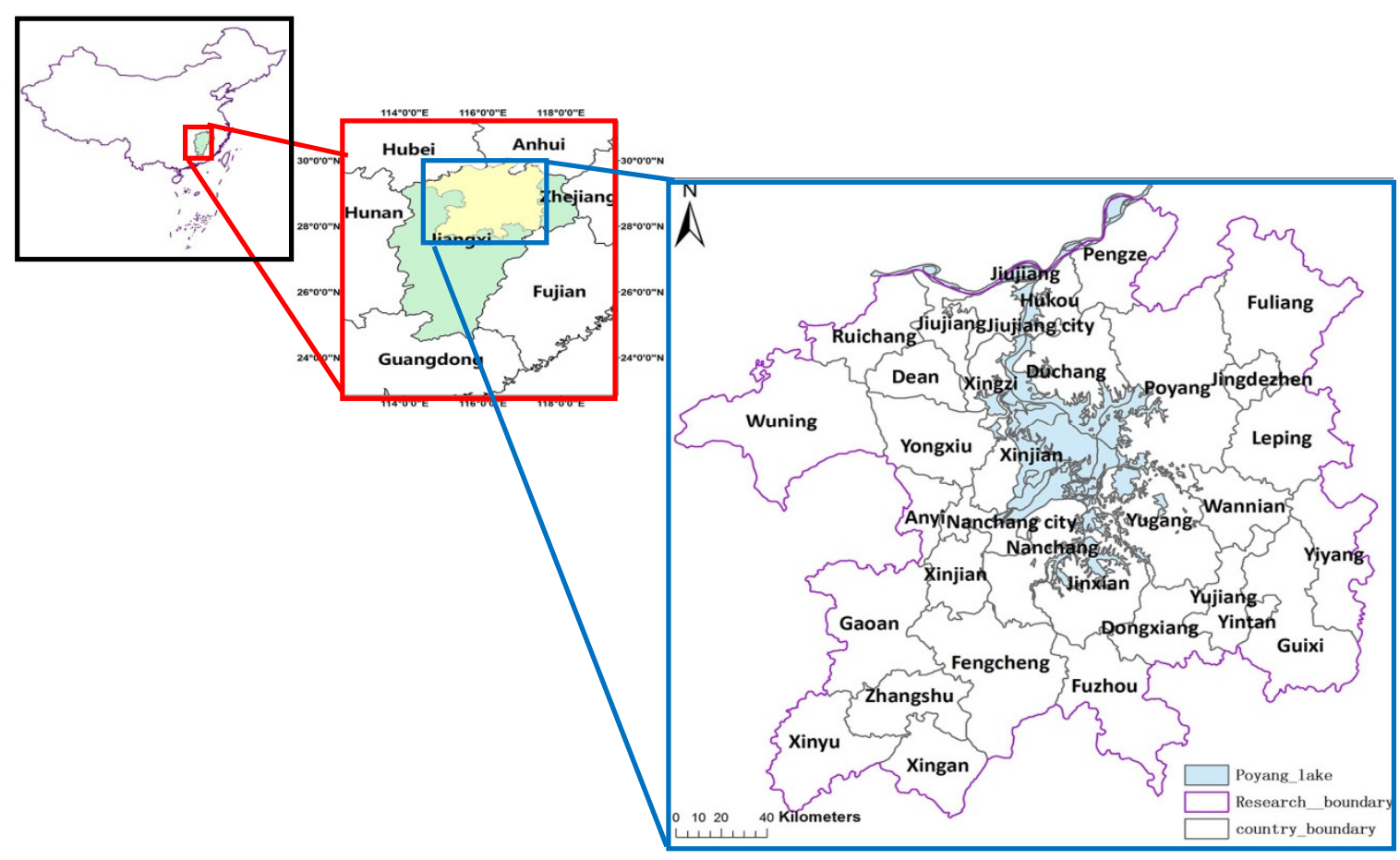

Figure 1. The Location of the Poyang Lake region.

\subsection{Sampling Techniques}

The data used in this study were collected by the authors in PLR from June to July 2018. We used a stratified random sampling method to choose samples. First, 12 counties were chosen from PLR based on pork production. Second, four villages in each county were chosen based on pork production. Finally, we randomly selected fifteen to twenty pig farmers in each village. Hence, 686 pig farmers in 48 villages from 12 counties were investigated.

We used a structured questionnaire to get first-hand data through face to face interviews. The questionnaire consisted of five sections. The first section focused on pig farmers' socioeconomic information, including age, education, pig breeding years, risk attitude, farm size, and off-farm labor. The second section related to information regarding pig breeding situation, including pig breeding size, pig breeding income, and others. The third section collected information on farmers' environmental awareness of manure. Farmers were investigated regarding their perception of the impacts of manure on the environment and human health and their willingness to treat manure. During the interview, farmers were required to give detailed information concerning their pig manure treatment approaches. The final section related to information regarding government support policies about pig manure treatment, such as biogas subsidy and technical training.

\subsection{Dependent Variables}

The adoption of manure treatment technologies in rural China is the dependent variable in our analysis. Five manure treatment approaches are mainly adopted in pig production in China, namely returning to the field, arbitrary discard, composting, producing biogas, and sale [5]. Table 1 shows the definition and impacts of different manure treatment technologies. The latter three technologies-Composting, Biogas, and sale - are defined as SMTTs because the environmental damage of these technologies is relatively low. The first two technologies, Returning and Discard, are not SMTTs because they are less environmentally friendly. 
Table 1. Definition and impacts of different manure treatment technologies.

\begin{tabular}{|c|c|c|c|}
\hline $\begin{array}{l}\text { Types of Manure } \\
\text { Treatment Approaches }\end{array}$ & Definition & Impacts & SMTTs or Not \\
\hline $\begin{array}{l}\text { Returning to the field } \\
\text { (Returning) }\end{array}$ & $\begin{array}{l}\text { Manure is directly returned to } \\
\text { the field as fertilizer without any } \\
\text { treatment }\end{array}$ & $\begin{array}{l}\text { Must consider how } \\
\text { much manure the land } \\
\text { can absorb and will } \\
\text { cause damage to the } \\
\text { environment. }\end{array}$ & No \\
\hline $\begin{array}{l}\text { Arbitrary discard } \\
\text { (Discard })\end{array}$ & $\begin{array}{l}\text { Manure is arbitrarily dumped } \\
\text { into land or river }\end{array}$ & $\begin{array}{l}\text { Impose serious } \\
\text { environmental damage }\end{array}$ & No \\
\hline $\begin{array}{l}\text { Composting technology } \\
\text { (Composting) }\end{array}$ & $\begin{array}{l}\text { Manure is composted to } \\
\text { generate organic fertilizer. }\end{array}$ & $\begin{array}{l}\text { Reducing the use of } \\
\text { chemical fertilizer and } \\
\text { the damage of manure }\end{array}$ & Yes \\
\hline $\begin{array}{l}\text { Producing biogas } \\
\text { technology (Biogas) }\end{array}$ & $\begin{array}{c}\text { Manure is collected and stored } \\
\text { in biogas digesters to produce } \\
\text { biogas. }\end{array}$ & $\begin{array}{c}\text { Alleviating energy } \\
\text { shortage in rural China }\end{array}$ & Yes \\
\hline Sale technology (Sale) & $\begin{array}{l}\text { Manure is sold to planting } \\
\text { farmers or agricultural factories } \\
\text { to produce organic fertilizer }\end{array}$ & $\begin{array}{l}\text { Reducing the use of } \\
\text { chemical fertilizer and } \\
\text { the damage of manure }\end{array}$ & Yes \\
\hline
\end{tabular}

\subsection{Independent Variables}

Based on previous literature on the adoption of sustainable agricultural technologies, especially manure treatment technologies, we categorize the factors influencing farmers' adoption of SMTTs into five categories: Individual characteristics, household characteristics, pig breeding characteristics, environmental awareness, and government support policies. Detailed descriptions of the explanatory variables and their expected effects on the adoption of manure treatment technologies are discussed below.

Individual characteristics. (1) Gender. Compared with younger farmers, older farmers might be more shortsighted and less physical and mental efficacy, resulting in a lower likelihood of adopting SMTTs [19]. (2) Education. We expect that education can increase the possibility of adopting SMTTs. Education can increase the farmers' ability to access new information about SMTTs [20]. In addition, farmers with higher education are more likely to recognize the benefits and constraints of new technologies [21]. (3) Leader. Being a village leader usually implies a wide interpersonal network [22]. Farmers who are village leaders can obtain more information about the benefits of new technologies and thus are more likely to adopt SMTTs. (4) Breeding experience. Breeding experience captures farmers' manure management knowledge gained through past experience. Farmers may continue their manure management behavior in the future based on their breeding experience [23]. Because SMTTs have not been widespread in the past in rural China, we expect that farmers with more breeding experience are less likely to adopt SMTTs. (5) Risk attitude. The adoption of SMTTs might be risky and challenging for pig farmers because it requires obvious changes in pig production and high financial input [24]. Therefore, we expect that farmers who are accepting of risk are more likely to adopt SMTTs, especially those technologies that require high financial investment, such as Biogas and Composting.

Household characteristics. (1) Farm size. Returning and Composting need sufficient farmland to absorb the generated manure [3]. Therefore, with the increase in farm size, the possibility of adopting Returning and Composting is higher, and the possibility of adopting Discard, Biogas, and Sale is lower. (2) Share of off-farm labor. The impact of the share of off-farm labor on adopting SMTTs is inconclusive. On one hand, with the increase of the share of off-farm labor, farmers would spend less time on livestock breeding and are less likely to adopt labor-intensive manure treatment technologies, such as Composting and Biogas [25]. On the other hand, a higher share of off-farm labor may allow farmers to have enough money to pay the high and long-term investment costs of SMTTs [26]. (3) Household income. We expect that households with higher income are more likely to adopt SMTTs, especially technologies that require high financial investment, such as Biogas and Composting. This is because adopting SMTTs requires high investment, while the economic returns are expected in the medium to long term [27]. 
Pig breeding characteristics. (1) Pig breeding scale. We hypothesize that pig breeding scale will increase the likelihood of adopting SMTTs. Increasing pig breeding scale leads to more generated manure and thus requires significant effort to address manure pollution [28]. Meanwhile, governmental manure treatment regulation is stricter with the increase of pig breeding scale. For instance, the "Prevention and Treatment on Pollution from Livestock Cultivation" enforced in 2014 stated that larger-scale pig breeding farmers (market pig inventory of more than 500) must adopt SMTTs to treat manure, otherwise they will face a pollution fine. In addition, farmers with larger pig breeding scale often have enough capital to invest in SMTTs [29]. (2) Share of pig breeding income. A higher share of pig breeding income implies that more importance is attached to pig breeding. In addition, compared with households with a lower share of pig breeding income, the benefits of adopting SMTTs in the long term are greater for households with a higher share of pig breeding income [1]. Thus, we expect that the share of pig breeding income has a positive impact on the adopting of SMTTs.

Environmental awareness. The theory of planned behavior has proven that awareness is a harbinger to a decision to take action [30]. Environmental awareness has been empirically confirmed to be a decisive influencing factor in the farmers' decision to adopt sustainable agricultural technologies [31]. We use three variables to proxy environmental awareness: Environmental impact awareness of manure, human health impact awareness of manure, and manure treatment willingness. We hypothesize that higher environmental awareness will induce farmers to adopt SMTTs.

Government support policies. Adopting SMTTs is, in fact, a public goods game. From the perspective of farmers, profit can be earned by neglecting to treat manure pollution, while public goods-the environment-could be lost because of untreated manure. Therefore, the Chinese government has provided different kinds of financial supports for the adoption of SMTTs [32]. There are mainly two kinds of subsidies for SMTTs. One is the biogas subsidy, which aims at inducing farmers to generate biogas from manure and the other is the composting subsidy, which encourages farmers to treat manure as composting fertilizers [7]. We proxy government support policies using the following three indicators: Biogas subsidy, composting subsidy, and technical training. We expect that government support policies will increase farmers' possibility of adopting SMTTs.

\subsection{Statistical Method}

A commonly used method in previous literature on the adoption of agricultural technologies is a univariate econometric method, such as probit or logit model [33]. However, as stated in the introduction, farmers will adopt a package of manure treatment technologies rather than a single technology to maximize their expected utility [14]. Farmers' adoption of different manure treatment technologies may be interdependent, either as complements (positive correlation) or as substitutes (negative correlation). Using univariate probit or logit models in such cases will result in biased and inefficient conclusions since univariate models ignore potential interdependence that exists between different manure treatment technologies [34-36].

Against this background, we apply a multivariate probit (MVP) modeling approach that can account for the correlation in the error terms of different manure treatment technologies adoption equations. MVP can estimate multiple technologies adoption models simultaneously while allowing unobserved and unmeasured factors (error terms) to be correlated [37]. Our MVP model comprises five binary choice equations, namely treatment technology of returning to the field, arbitrary discard, composting, producing biogas, and sale. As a result, we have five dependent binary variables $Y_{i j}^{*}$ for a farmer. The MVP model is specified as:

$$
\begin{gathered}
Y_{i j}^{*}=\beta_{j} X_{i}+\mu_{i j}, j=1,2,3,4,5 \\
\mathrm{Y}_{\mathrm{ij}}= \begin{cases}1 & \text { if } \mathrm{Y}_{\mathrm{ij}}^{*}>0 \\
0 & \text { otherwise }\end{cases}
\end{gathered}
$$


where $j$ represents the choices of five manure treatment technologies; $Y_{i j}^{*}$ denotes the latent variable captured the level of expected utility derived from the choice of technology $j$; this latent variable is assumed to be a linear combination of observed characteristics, $X_{i}$, including pig farmers' individual characteristics, household characteristics, pig breeding characteristics, environmental awareness and government support policies, and unobserved characteristics captured by the stochastic error term, $\mu_{i j}$, $\beta_{j}$ are vectors of coefficients to be estimated. Given the latent nature of $Y_{i j}^{*}$, estimation is based on observable binary variables $Y_{i j}$, which is a binary observable variable showing whether or not farmers adopt the technology.

In the MVP model, the error terms $\mu_{i j}(j=1,2,3,4,5)$ are assumed to jointly follow a multivariate normal distribution (MVN) with conditional mean 0 and a variance-covariance matrix $\Psi$, namely $\mu_{i j} \approx$ $\operatorname{MVN}(0, \Psi)$. The variance-covariance matrix $\Psi$ has value 1 on the leading diagonal, and correlations $\rho_{i j}=\rho_{j i}$ as off-diagonal elements. The symmetric variance-covariance matrix is given as follows:

$$
\Psi=\left[\begin{array}{ccccc}
1 & \rho_{12} & \rho_{13} & \rho_{14} & \rho_{15} \\
\rho_{12} & 1 & \rho_{23} & \rho_{24} & \rho_{25} \\
\rho_{13} & \rho_{23} & 1 & \rho_{34} & \rho_{35} \\
\rho_{14} & \rho_{24} & \rho_{34} & 1 & \rho_{45} \\
\rho_{15} & \rho_{25} & \rho_{35} & \rho_{45} & 1
\end{array}\right]
$$

where $\rho$ (rho) refers to the pairwise correlation coefficient of the error terms corresponding to any two manure treatment technologies adoption equations to be estimated. $\rho$ provides information on the correlation relationship between different manure treatment technologies. If $\rho$ is significantly positive, then there is a complementary relationship between different manure treatment technologies. If $\rho$ is significantly negative, then there is a substituted relationship between different manure treatment technologies.

\section{Results and Discussion}

\subsection{Descriptive Statistics of the Survey}

The statistical description and expected signs of independent variables are presented in Table 2. The average age of the surveyed samples is 48 years and most farmers have six years of education, which is in consistent with the fact that most farmers in China being middle-aged with poor education [38]. One-quarter of the surveyed respondents are village leaders. Most farmers are risk averse and have seven years of pig breeding experience. On average, farmers have $1.78 \mathrm{mu}(0.11 \mathrm{ha})$ farmland areas and the share of off-farm labor is almost $50 \%$, which is in accordance with most farmers in China being small-scale and highly engaged in off-farm activities [39]. The average household income is nearly RMB 48,000 (\$ 6952), which is close to the average household income in Jiangxi province in 2017. The environmental awareness of pig production was relatively low, with most surveyed respondents believing that manure has a little negative effect on the environment and has nearly no negative effect on human health. Nevertheless, most pig farmers (78\%) are willing to treat manure in a sustainable way. Most farmers have received biogas subsidies and composting subsidies from the government, but only $12 \%$ of samples have participated in technical training on manure treatment.

In sum, our surveyed samples are in consistent with the Chinese agricultural population in age, education, farm size, share of off-farm income, and household income. 
Table 2. Variable definitions and expected signs.

\begin{tabular}{|c|c|c|c|c|c|c|c|c|}
\hline \multirow{2}{*}{ Variables } & \multirow{2}{*}{ Definition } & \multirow{2}{*}{ Mean } & \multirow{2}{*}{ Std. Dev. } & \multicolumn{5}{|c|}{ Expected Sign } \\
\hline & & & & Discard & Returning & Biogas & Sale & Composting \\
\hline \multicolumn{9}{|c|}{ Individual characteristics } \\
\hline Age & $\begin{array}{l}\text { Age of household } \\
\text { head (years) }\end{array}$ & 48.29 & 11.27 & + & + & - & $+/-$ & - \\
\hline Education & $\begin{array}{l}\text { Education of } \\
\text { household head } \\
\text { (years) }\end{array}$ & 7.35 & 2.89 & - & - & + & + & + \\
\hline Leader & $\begin{array}{c}1=\text { household head } \\
\text { is village leader; } \\
0=\text { otherwise }\end{array}$ & 0.16 & 0.36 & - & - & + & + & + \\
\hline $\begin{array}{l}\text { Breeding } \\
\text { experience }\end{array}$ & Years breeding pigs & 7.26 & 0.87 & + & + & - & $+/-$ & - \\
\hline $\begin{array}{l}\text { Risk } \\
\text { attitude }\end{array}$ & $\begin{array}{c}1=\text { risk-accepting } \\
2=\text { risk-neutral; } \\
3=\text { risk-aversion }\end{array}$ & 2.31 & 0.69 & + & + & - & $+/-$ & - \\
\hline \multicolumn{9}{|c|}{ Household characteristics } \\
\hline Farm size & $\begin{array}{l}\text { Cultivated land area } \\
\text { per capita } \\
\text { (mu/person) }\end{array}$ & 1.78 & 8.43 & - & + & - & - & + \\
\hline $\begin{array}{l}\text { Share of } \\
\text { off-farm } \\
\text { labor }\end{array}$ & $\begin{array}{l}\text { Share of off-farm } \\
\text { labor in the total } \\
\text { labor (\%) }\end{array}$ & 0.47 & 0.29 & + & - & - & + & - \\
\hline $\begin{array}{l}\text { Household } \\
\text { income }\end{array}$ & $\begin{array}{l}\text { Household income } \\
\text { (thousand RMB) }\end{array}$ & 48.98 & 58.25 & $+/-$ & - & + & $+/-$ & + \\
\hline \multicolumn{9}{|c|}{ Pig breeding characteristics } \\
\hline $\begin{array}{l}\text { Pig } \\
\text { breeding } \\
\text { scale }\end{array}$ & $\begin{array}{l}\text { Number of pigs } \\
\text { owned by the } \\
\text { household }\end{array}$ & 235.6 & 1214.46 & - & - & + & + & + \\
\hline $\begin{array}{l}\text { Share of } \\
\text { pig } \\
\text { breeding } \\
\text { income }\end{array}$ & $\begin{array}{c}\text { Share of pig } \\
\text { breeding income }(\%)\end{array}$ & 0.52 & 0.44 & - & - & + & + & + \\
\hline \multicolumn{9}{|c|}{ Environmental awareness } \\
\hline $\begin{array}{l}\text { Environmental } \\
\text { impact } \\
\text { awareness } \\
\text { of manure }\end{array}$ & $\begin{array}{c}1=\text { nearly no } \\
\text { negative impact; } \\
2=\text { little negative } \\
\text { impact; } 3=\text { less } \\
\text { serious negative } \\
\text { impact; } 4=\text { serious } \\
\text { negative impact }\end{array}$ & 2.08 & 1.56 & - & - & + & $+/-$ & + \\
\hline $\begin{array}{l}\text { Human } \\
\text { health } \\
\text { impact } \\
\text { awareness } \\
\text { of manure }\end{array}$ & $\begin{array}{c}1=\text { nearly no } \\
\text { negative impact; } \\
2=\text { little negative } \\
\text { impact; } 3=\text { less } \\
\text { serious negative } \\
\text { impact; } 4 \text { = serious } \\
\text { negative impact }\end{array}$ & 1.42 & 0.92 & - & - & + & $+/-$ & + \\
\hline $\begin{array}{c}\text { Manure } \\
\text { treatment } \\
\text { willingness }\end{array}$ & $\begin{array}{c}1=\text { willing to treat } \\
\text { manure in a } \\
\text { sustainable way; } \\
0=\text { otherwise }\end{array}$ & 0.78 & 0.45 & - & - & + & $+/-$ & + \\
\hline
\end{tabular}


Table 2. Cont.

\begin{tabular}{|c|c|c|c|c|c|c|c|c|}
\hline \multirow{2}{*}{ Variables } & \multirow{2}{*}{ Definition } & \multirow{2}{*}{ Mean } & \multirow{2}{*}{ Std. Dev. } & \multicolumn{5}{|c|}{ Expected Sign } \\
\hline & & & & Discard & Returning & Biogas & Sale & Composting \\
\hline \multicolumn{9}{|c|}{ Government support policies } \\
\hline $\begin{array}{l}\text { Biogas } \\
\text { subsidy }\end{array}$ & $\begin{array}{l}\text { The logarithm of the } \\
\text { amount of biogas } \\
\text { subsidy farmers } \\
\text { received }\end{array}$ & 4.36 & 2.35 & - & - & + & $+/-$ & + \\
\hline $\begin{array}{c}\text { Composting } \\
\text { subsidy }\end{array}$ & $\begin{array}{l}\text { The logarithm of the } \\
\text { amount of } \\
\text { composting subsidy } \\
\text { farmers received }\end{array}$ & 2.01 & 1.87 & & & & & \\
\hline $\begin{array}{l}\text { Technical } \\
\text { training }\end{array}$ & $\begin{array}{c}1=\text { if the farmer has } \\
\text { participated in } \\
\text { technical training } \\
\text { about manure } \\
\text { treatment; } \\
0=\text { otherwise }\end{array}$ & 0.12 & 0.28 & - & - & + & $+/-$ & + \\
\hline
\end{tabular}

Data source: Author's survey, 2018; Note: "+" indicates the effect of this variable is positive; "-" indicates the effect of this variable is negative; "+/-" indicates the effect of this variable is not sure.

\subsection{Statistical Analyses of Variables}

\subsubsection{Statistical Analyses of Dependent Variables}

Figure 2 shows the proportion of farmers adopting different manure treatment technologies in pig production in our survey. It implies that Returning is the main manure treatment technology in that $62 \%$ of the pig farmers in our sample adopt it. Other treatments, Biogas, Discard, Composting, and Sale are used by $26 \%, 18 \%, 14 \%$, and $11 \%$ of pig farmers, respectively. These figures indicate that SMTTs is not widely adopted in rural China, as only $58 \%$ of pig farmers have adopted Biogas, Composting, and Sale. As a result, there is still great potential to enhance the adoption of SMTTs. In addition, our results show that $63 \%$ of pig farmers have adopted at least two manure treatment technologies, which indicates that farmers adopt a bundle of technologies rather than a single one.

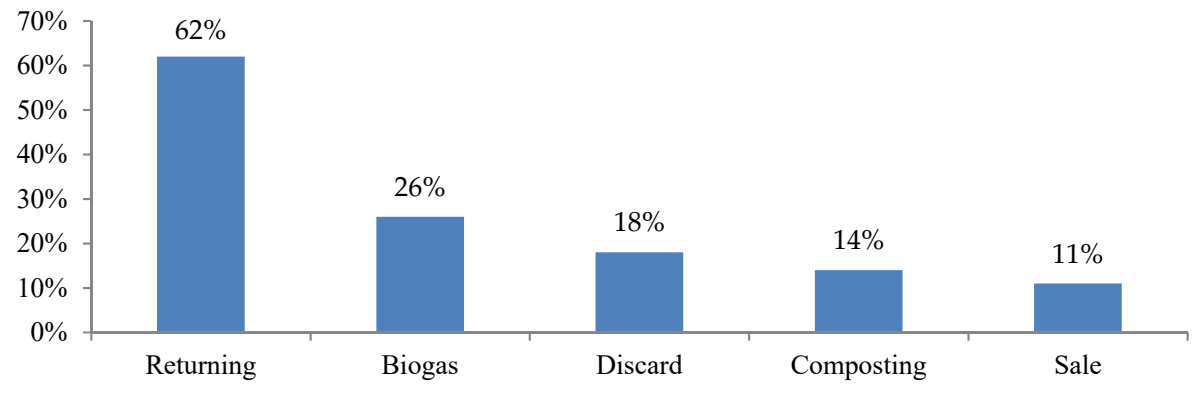

Figure 2. The proportion of pig farmers adopting different manure treatment technologies in rural China. Data source: Author's survey, 2018; Note: Farmers may adopt multiple manure treatment technologies, so the total proportion exceeds $100 \%$.

Our survey results are consistent with previous studies. For example, Huang et al. [13] reported that $9.76 \%$ of pig farmers sold their manure to markets. Chadwick et al. [3] showed that $66 \%$ of farmers recycled manure into farmland and almost $20 \%$ of farmers discarded manure into rivers or lakes. Wei et al. [40] found that almost $15 \%$ of farmers adopted composting technology and nearly $28 \%$ of farmers adopted biogas technology to treat pig manure.

\subsubsection{Statistical Analyses of Independent Variables}

Table 3 shows the statistical analyses of the relationship of different independent variables and the adoption rates of SMTTs. The results are in line with our expectation stated in Section 2.4. For example, 
farmers that are younger, higher-educated, have more breeding experience, and risk-accepting are more likely to adopt SMTTs. Households with more farmland, lower share of off-farm labor, more household income, larger pig breeding scale, and higher share of pig breeding income have a higher possibility to adopt SMTTs. Farmers with higher environmental awareness and government subsidy are also more likely to adopt SMTTs.

However, this simple statistical analysis has no causal interpretation of the impact of independent variables on the adoption of SMTTs. Therefore, in the next section, we will use the MVP model that can control for other factors to empirically examine the effect of independent variables on SMTT' adoption.

Table 3. Statistical analyses of independent variables.

\begin{tabular}{|c|c|c|c|c|c|c|}
\hline \multirow{2}{*}{ Variables } & \multirow{2}{*}{ Category } & \multicolumn{5}{|c|}{ Adopting Rates } \\
\hline & & Discard & Returning & Biogas & Sale & Composting \\
\hline \multirow{4}{*}{ Age } & $\leq 30$ & $12.28 \%$ & $38.6 \%$ & $49.12 \%$ & $14.04 \%$ & $19.3 \%$ \\
\hline & $30-40$ & $14.29 \%$ & $57.82 \%$ & $25.85 \%$ & $12.24 \%$ & $16.33 \%$ \\
\hline & $40-50$ & $14.55 \%$ & $63.33 \%$ & $23.03 \%$ & $11.52 \%$ & $13.64 \%$ \\
\hline & $\geq 50$ & $16.36 \%$ & $68.64 \%$ & $18.18 \%$ & $11.36 \%$ & $12.27 \%$ \\
\hline \multirow{4}{*}{ Education (year) } & $\leq 6$ & $21.96 \%$ & $65.49 \%$ & $15.29 \%$ & $9.81 \%$ & $12.16 \%$ \\
\hline & $6-9$ & $13.75 \%$ & $61.89 \%$ & $27.22 \%$ & $10.03 \%$ & $13.18 \%$ \\
\hline & $9-12$ & $9.17 \%$ & $63.89 \%$ & $27.78 \%$ & $16.67 \%$ & $13.89 \%$ \\
\hline & $\geq 12$ & $4.76 \%$ & $38.1 \%$ & $57.14 \%$ & $28.57 \%$ & $26.19 \%$ \\
\hline \multirow{2}{*}{ Leader } & Yes & $10.12 \%$ & $31.36 \%$ & $36.56 \%$ & $20.32 \%$ & $25.21 \%$ \\
\hline & No & $20.68 \%$ & $58.43 \%$ & $19.89 \%$ & $9.95 \%$ & $20.78 \%$ \\
\hline \multirow{3}{*}{ Breeding experience (year) } & $\leq 5$ & $15.74 \%$ & $51.8 \%$ & $27.21 \%$ & $11.48 \%$ & $11.48 \%$ \\
\hline & $5-10$ & $13.85 \%$ & $64.23 \%$ & $28.85 \%$ & $11.54 \%$ & $14.62 \%$ \\
\hline & $\geq 10$ & $16.93 \%$ & $75.66 \%$ & 15.87 & $7.94 \%$ & $11.11 \%$ \\
\hline \multirow{3}{*}{ Risk attitude } & Risk-accepting & $10.62 \%$ & $48.67 \%$ & $28.33 \%$ & $27.43 \%$ & $13.33 \%$ \\
\hline & Risk-neutral & $20.45 \%$ & $61.1 \%$ & $25.19 \%$ & $8.73 \%$ & $11.47 \%$ \\
\hline & Risk-aversion & $9.17 \%$ & $70.05 \%$ & $19.47 \%$ & $5.83 \%$ & $9.73 \%$ \\
\hline \multirow{3}{*}{ Farm size $(\mathrm{mu})$} & $\leq 1$ & $15.48 \%$ & $57.12 \%$ & $24.91 \%$ & $11.92 \%$ & $10.32 \%$ \\
\hline & $1-2$ & $17.76 \%$ & $58.88 \%$ & $25.23 \%$ & $9.35 \%$ & $20.56 \%$ \\
\hline & $\geq 2$ & $11.76 \%$ & $62.35 \%$ & $24.71 \%$ & $3.53 \%$ & $16.47 \%$ \\
\hline \multirow{4}{*}{ Share of off-farm labor } & $\leq 20 \%$ & $3.61 \%$ & $81.93 \%$ & $12.05 \%$ & $8.43 \%$ & $9.64 \%$ \\
\hline & $20 \%-50 \%$ & $13.69 \%$ & $61.73 \%$ & $26.54 \%$ & $9.51 \%$ & $15.36 \%$ \\
\hline & $50 \%-80 \%$ & $21.26 \%$ & $61.02 \%$ & $25.59 \%$ & $6.32 \%$ & $11.42 \%$ \\
\hline & $\geq 80 \%$ & $16.95 \%$ & $40.68 \%$ & $30.51 \%$ & $38.98 \%$ & $3.39 \%$ \\
\hline \multirow{2}{*}{ Household income } & Low & $25.67 \%$ & $67.89 \%$ & $17.32 \%$ & $8.15 \%$ & $13.24 \%$ \\
\hline & High & $13.12 \%$ & $43.21 \%$ & $36.34 \%$ & $18.91 \%$ & $17.81 \%$ \\
\hline \multirow{3}{*}{ Pig breeding scale } & $\leq 50$ & $15.31 \%$ & $72.56 \%$ & $16.12 \%$ & $4.17 \%$ & $12.92 \%$ \\
\hline & $50-500$ & $17.33 \%$ & $42.08 \%$ & $40.59 \%$ & $22.28 \%$ & $9.93 \%$ \\
\hline & $\geq 500$ & $8.16 \%$ & $36.73 \%$ & $46.94 \%$ & $28.57 \%$ & $24.49 \%$ \\
\hline \multirow{4}{*}{$\begin{array}{l}\text { Share of pig breeding } \\
\text { income }\end{array}$} & $\leq 20 \%$ & $16.67 \%$ & $54.84 \%$ & $29.03 \%$ & $3.76 \%$ & $20.43 \%$ \\
\hline & $20 \%-50 \%$ & $15.19 \%$ & $58.86 \%$ & $34.18 \%$ & $6.96 \%$ & $17.09 \%$ \\
\hline & $50 \%-80 \%$ & $12.84 \%$ & $58.78 \%$ & $20.95 \%$ & $18.92 \%$ & $4.73 \%$ \\
\hline & $\geq 80 \%$ & $16.03 \%$ & $62.98 \%$ & $30.15 \%$ & $12.98 \%$ & $8.46 \%$ \\
\hline \multirow{4}{*}{$\begin{array}{l}\text { Environmental impact } \\
\text { awareness of manure }\end{array}$} & Nearly no negative impact & $22.87 \%$ & $73.93 \%$ & $9.97 \%$ & $9.25 \%$ & $14.08 \%$ \\
\hline & Little negative impact & $20.11 \%$ & $58.05 \%$ & $27.01 \%$ & $15.52 \%$ & $17.24 \%$ \\
\hline & Less serious negative impact & $18.11 \%$ & $50.39 \%$ & $38.58 \%$ & $9.45 \%$ & $7.09 \%$ \\
\hline & Serious negative impact & $13.39 \%$ & $45.54 \%$ & $51.79 \%$ & $6.25 \%$ & $6.25 \%$ \\
\hline \multirow{4}{*}{$\begin{array}{l}\text { Human health impact } \\
\text { awareness of manure }\end{array}$} & Nearly no negative impact & $20.82 \%$ & $68.45 \%$ & $17.81 \%$ & $12.66 \%$ & $14.59 \%$ \\
\hline & Little negative impact & $23.16 \%$ & $59.32 \%$ & $31.07 \%$ & $5.65 \%$ & $12.43 \%$ \\
\hline & Less serious negative impact & $18.31 \%$ & $50.71 \%$ & $33.83 \%$ & $15.49 \%$ & $4.23 \%$ \\
\hline & Serious negative impact & $15.11 \%$ & $20.32 \%$ & $40.21 \%$ & $2.56 \%$ & $2.75 \%$ \\
\hline \multirow{2}{*}{$\begin{array}{l}\text { Manure treatment } \\
\text { willingness }\end{array}$} & Yes & $16.58 \%$ & $82.76 \%$ & $15.17 \%$ & $3.45 \%$ & $0.69 \%$ \\
\hline & No & $10.34 \%$ & $57.14 \%$ & $27.26 \%$ & $12.32 \%$ & $15.27 \%$ \\
\hline \multirow{2}{*}{ Biogas subsidy } & Low & $19.12 \%$ & $65.32 \%$ & $16.75 \%$ & $10.18 \%$ & $13.21 \%$ \\
\hline & High & $18.76 \%$ & $59.89 \%$ & $67.85 \%$ & $11.21 \%$ & $14.36 \%$ \\
\hline \multirow{2}{*}{ Composting subsidy } & Low & $17.63 \%$ & $64.35 \%$ & $25.35 \%$ & $10.22 \%$ & $11.82 \%$ \\
\hline & High & $18.25 \%$ & $60.04 \%$ & $26.12 \%$ & $12.03 \%$ & $32.45 \%$ \\
\hline \multirow{2}{*}{ Technical training } & Yes & $16.41 \%$ & $62.38 \%$ & $24.33 \%$ & $10.61 \%$ & $12.59 \%$ \\
\hline & No & $2.13 \%$ & $57.45 \%$ & $34.04 \%$ & $10.64 \%$ & $14.89 \%$ \\
\hline
\end{tabular}




\subsection{Interdependence of SMTTs}

Table 4 shows the estimates of the binary correlations between the error terms of the five adoption equations. It shows SMTTs are interdependent with each other. The likelihood ratio test $\left(\chi^{2}(10)=86.24\right.$; Prob $>\chi^{2}=0.000$ ) of the independence of different manure treatment technologies' adoption rejected the null hypothesis of zero correlation between the error terms, suggesting that the adoption of different manure treatment technologies is not mutually independent. Therefore, the MVP is more appropriate than the single-equation probit or logit models. Significant coefficients between different manure treatment technologies also support the assumption that different manure treatment technologies are not adopted independently of each other. Specifically, we find five relations of substitutability and one relation of complementarity. In particular, there is a substitute relationship between Discard and Biogas, Returning and Biogas, Returning and Composting, Biogas and Sale, and Biogas and Composting, while there is a complementary relationship between Returning and Discard.

Table 4. Correlation coefficient estimates for multivariate probit model (MVP) regression equations.

\begin{tabular}{lccccc}
\hline Approaches & Discard & Returning & Biogas & Sale & Composting \\
\hline Discard & - & - & - & - & - \\
Returning & $0.397^{* * *}(0.125)$ & - & - & - & - \\
Biogas & $-0.214^{* *}(0.103)$ & $-0.354^{* * *}(0.102)$ & - & - & - \\
Sale & $-0.132(0.104)$ & $-0.295(0.179)$ & $-0.197^{* * *}(0.049)$ & - & - \\
Composting & $-0.198(0.232)$ & $-0.326^{* * *}(0.084)$ & $-0.479 * *(0.121)$ & $0.127(0.078)$ & - \\
\hline Note: (1) Likelihood ratio test of $\rho_{21}=\rho_{31}=\rho_{41}=\rho_{51}=\rho_{32}=\rho_{42}=\rho_{52}=\rho_{43}=\rho_{53}=\rho_{54}=0 ;$ \\
$\chi^{2}(10)=86.24 ;$ Prob $>\chi^{2}=0.000 .(2){ }^{* * *},{ }^{* *}$ denote statistical significance at the one percent and five percent \\
levels, respectively.
\end{tabular}

\subsection{MVP Estimation Results}

The estimation results of the determinants of farmers' adoption of SMTTs are presented in Table 5. We find that most of the estimated coefficients for individual characteristics, government support policies, and environmental awareness are in line with our expectations.

\subsubsection{Individual Characteristics}

As expected, age has a significant positive impact on Discard and Returning, indicating that older farmers are more likely to choose unsustainable manure treatment technologies than younger farmers are. Education plays a negative role in the adoption of Discard and Returning, while a significant positive impact of education is found on Biogas and Sale. These results indicate that education can promote the adoption of SMTTs, which is in accordance with the conclusion of previous studies [15]. However, the correlation between education and Composting is not significant, which contradicts our expectation. A possible reason is that just as Table 4 shows, Composting and Biogas are substitutes, farmers can substitute Composting by choosing Biogas, resulting in a positive effect on Biogas while no effect on Composting.

Being a village leader can increase the adoption of Biogas and Sale. Two possible explanations are as follows. First, village leaders have higher abilities for information acquisition and technology acceptance than ordinary farmers do, which enhances the possibility of adopting SMTTs. Second, village leaders in rural China can often obtain more government subsidies due to their close connection with upper government levels [41]. According to the survey data of our sample, government subsidies for SMTTs allocated to village leaders are four times higher than those allocated to ordinary farmers. This high government subsidy decreases the financial cost of adopting SMTTs for village leaders and thus increases their likelihood of adopting.

The coefficient of breeding experience is not significant in all five models, indicating that breeding experience has no impact on the adoption of SMTTs. Our results also indicate that compared with risk-averse farmers, farmers who are accepting of risk are more likely to adopt Biogas and Composting, which is consistent with our expectation. However, the adoption behavior of risk-neutral farmers is almost the same as that of risk-averse farmers. 
Table 5. Estimates of the multivariate probit model.

\begin{tabular}{|c|c|c|c|c|c|}
\hline Variables & Discard & Returning & Biogas & Sale & Composting \\
\hline \multicolumn{6}{|l|}{ Individual characteristics } \\
\hline Age & $\begin{array}{l}0.030 \text { * } \\
(0.016)\end{array}$ & $\begin{array}{l}0.024 * \\
(0.013)\end{array}$ & $\begin{array}{l}-0.002 \\
(0.010)\end{array}$ & $\begin{array}{l}-0.019 \\
(0.017)\end{array}$ & $\begin{array}{l}-0.002 \\
(0.011)\end{array}$ \\
\hline Education & $\begin{array}{c}-0.233 \text { * } \\
(0.127)\end{array}$ & $\begin{array}{c}-0.216 * \\
(0.116)\end{array}$ & $\begin{array}{l}0.164 \text { * } \\
(0.086)\end{array}$ & $\begin{array}{c}-0.166 \text { * } \\
(0.096)\end{array}$ & $\begin{array}{c}0.024 \\
(0.146)\end{array}$ \\
\hline Leader & $\begin{array}{l}-0.234 \\
(0.466)\end{array}$ & $\begin{array}{l}-0.254 \\
(0.274)\end{array}$ & $\begin{array}{l}0.303 * \\
(0.167)\end{array}$ & $\begin{array}{l}0.157^{*} \\
(0.083)\end{array}$ & $\begin{array}{l}-0.522 \\
(0.536)\end{array}$ \\
\hline Breeding experience & $\begin{array}{c}0.007 \\
(0.021)\end{array}$ & $\begin{array}{c}0.012 \\
(0.011)\end{array}$ & $\begin{array}{l}-0.013 \\
(0.012)\end{array}$ & $\begin{array}{c}0.026 \\
(0.025)\end{array}$ & $\begin{array}{l}-0.009 \\
(0.016)\end{array}$ \\
\hline \multicolumn{6}{|c|}{ Risk attitude (Risk-adverse farmers as reference) } \\
\hline Risk-accepting farmers & $\begin{array}{l}-0.365 \\
(0.331)\end{array}$ & $\begin{array}{l}-0.231 \\
(0.256)\end{array}$ & $\begin{array}{c}0.075^{* * *} \\
(0.022)\end{array}$ & $\begin{array}{c}0.031 \\
(0.114)\end{array}$ & $\begin{array}{l}0.062 * * \\
(0.031)\end{array}$ \\
\hline Risk-neutral farmers & $\begin{array}{l}-0.223 \\
(0.167)\end{array}$ & $\begin{array}{l}-0.042 \\
(0.193)\end{array}$ & $\begin{array}{l}-0.087 \\
(0.121)\end{array}$ & $\begin{array}{l}-0.224 \\
(0.156)\end{array}$ & $\begin{array}{c}0.153 \\
(0.115)\end{array}$ \\
\hline \multicolumn{6}{|l|}{ Household characteristics } \\
\hline Farm size & $\begin{array}{c}-0.021^{* * * *} \\
(0.008)\end{array}$ & $\begin{array}{l}0.050 * * \\
(0.025)\end{array}$ & $\begin{array}{l}-0.001 \\
(0.007)\end{array}$ & $\begin{array}{c}-0.469 \text { **** } \\
(0.169)\end{array}$ & $\begin{array}{l}0.012 * \\
(0.007)\end{array}$ \\
\hline Share of off-farm labor & $\begin{array}{l}0.089 * * \\
(0.048)\end{array}$ & $\begin{array}{c}-0.053^{* *} \\
(0.026)\end{array}$ & $\begin{array}{c}0.071 \\
(0.079)\end{array}$ & $\begin{array}{l}0.052 * * \\
(0.026)\end{array}$ & $\begin{array}{c}-0.067 \text { * } \\
(0.038)\end{array}$ \\
\hline Household income & $\begin{array}{c}0.000 \\
(0.000)\end{array}$ & $\begin{array}{l}-0.015^{* *} \\
(0.008)\end{array}$ & $\begin{array}{c}0.000 \\
(0.000)\end{array}$ & $\begin{array}{l}-0.001 \\
(0.001)\end{array}$ & $\begin{array}{c}0.000 \\
(0.000)\end{array}$ \\
\hline \multicolumn{6}{|l|}{ Pig breeding characteristics } \\
\hline \multirow{2}{*}{$\begin{array}{l}\text { Pig breeding scale } \\
\text { Share of pig breeding income }\end{array}$} & $\begin{array}{c}-0.004^{* * * *} \\
(0.001)\end{array}$ & $\begin{array}{c}-0.003^{* *} \\
(0.001)\end{array}$ & $\begin{array}{l}0.002 * \\
(0.001)\end{array}$ & $\begin{array}{c}0.003^{* * *} \\
(0.001)\end{array}$ & $\begin{array}{l}0.003 \text { ** } \\
(0.001)\end{array}$ \\
\hline & $\begin{array}{c}0.025 \\
(0.091)\end{array}$ & $\begin{array}{l}0.022^{* *} \\
(0.011)\end{array}$ & $\begin{array}{l}-0.039 \\
(0.038) \\
\end{array}$ & $\begin{array}{c}0.071 \\
(0.097)\end{array}$ & $\begin{array}{l}-0.042 \\
(0.059)\end{array}$ \\
\hline \multicolumn{6}{|l|}{ Environmental awareness } \\
\hline \multicolumn{6}{|c|}{ Environmental impact awareness of manure (nearly no negative impact as reference) } \\
\hline Little negative impact & $\begin{array}{c}0.254 \\
(0.179)\end{array}$ & $\begin{array}{l}-0.289 \\
(0.198)\end{array}$ & $\begin{array}{c}0.197 \\
(0.186)\end{array}$ & $\begin{array}{l}-0.225 \\
(0.172)\end{array}$ & $\begin{array}{c}0.153 \\
(0.124)\end{array}$ \\
\hline Less serious negative impact & $\begin{array}{l}-0.258 \\
(0.197)\end{array}$ & $\begin{array}{l}-0.264^{*} \\
(0.145)\end{array}$ & $\begin{array}{l}0.642 * * * \\
(0.224)\end{array}$ & $\begin{array}{c}0.226 \\
(0.213)\end{array}$ & $\begin{array}{c}0.289 \\
(0.204)\end{array}$ \\
\hline Serious negative impact & $\begin{array}{l}-0.468^{* *} \\
(0.233)\end{array}$ & $\begin{array}{l}-0.215^{* * *} \\
(0.073)\end{array}$ & $\begin{array}{l}0.641^{* *} \\
(0.284)\end{array}$ & $\begin{array}{l}-0.236 \\
(0.184)\end{array}$ & $\begin{array}{l}0.173 \\
(0.117)\end{array}$ \\
\hline \multicolumn{6}{|c|}{ Human health impact awareness of manure(nearly no negative impact as reference) } \\
\hline Little negative impact & $\begin{array}{c}0.079 \\
(0.122)\end{array}$ & $\begin{array}{c}0.084 \\
(0.075)\end{array}$ & $\begin{array}{c}0.035 \\
(0.046)\end{array}$ & $\begin{array}{l}-0.127 \\
(0.095)\end{array}$ & $\begin{array}{l}-0.321 \\
(0.238)\end{array}$ \\
\hline Less serious negative impact & $\begin{array}{l}-0.156 \\
(0.213)\end{array}$ & $\begin{array}{c}0.187 \\
(0.121)\end{array}$ & $\begin{array}{l}0.265^{*} \\
(0.136)\end{array}$ & $\begin{array}{l}-0.132 \\
(0.204)\end{array}$ & $\begin{array}{l}-0.641 \\
(0.432)\end{array}$ \\
\hline Serious negative impact & $\begin{array}{l}-0.221 * * \\
(0.094)\end{array}$ & $\begin{array}{c}-0.379^{* * * *} \\
(0.123)\end{array}$ & $\begin{array}{l}0.187^{* * *} \\
(0.052)\end{array}$ & $\begin{array}{c}0.321 \\
(0.256)\end{array}$ & $\begin{array}{l}0.542 \\
(0.432)\end{array}$ \\
\hline Manure treatment willingness & $\begin{array}{c}-0.459^{* * * *} \\
(0.104)\end{array}$ & $\begin{array}{c}-0.801^{* * *} \\
(0.255)\end{array}$ & $\begin{array}{c}0.534^{* *} \\
(0.248)\end{array}$ & $\begin{array}{c}0.216^{* *} \\
(0.114)\end{array}$ & $\begin{array}{c}0.136 \text { ** } \\
(0.065)\end{array}$ \\
\hline \multicolumn{6}{|l|}{ Government support policies } \\
\hline Biogas subsidy & $\begin{array}{l}-0.042 \\
(0.121)\end{array}$ & $\begin{array}{l}-0.037 \\
(0.053)\end{array}$ & $\begin{array}{c}0.024 \\
(0.054)\end{array}$ & $\begin{array}{l}-0.066 \\
(0.112)\end{array}$ & $\begin{array}{c}0.077 \\
(0.132)\end{array}$ \\
\hline Composting subsidy & $\begin{array}{l}-0.065 \\
(0.127)\end{array}$ & $\begin{array}{l}-0.023 \\
(0.073)\end{array}$ & $\begin{array}{c}0.016 \\
(0.087)\end{array}$ & $\begin{array}{l}0.076 \\
(0.101)\end{array}$ & $\begin{array}{l}0.025^{* *} \\
(0.013)\end{array}$ \\
\hline Technical training & $\begin{array}{c}-0.128 * \\
(0.070)\end{array}$ & $\begin{array}{l}-0.096 \\
(0.132)\end{array}$ & $\begin{array}{c}0.002 \\
(0.253)\end{array}$ & $\begin{array}{c}0.284 \\
(0.195)\end{array}$ & $\begin{array}{c}0.119 \\
(0.252)\end{array}$ \\
\hline Constant & $\begin{array}{c}-4.139^{* * *} \\
(1.452)\end{array}$ & $\begin{array}{c}3.345^{* * *} \\
(0.862)\end{array}$ & $\begin{array}{c}-4.327^{* * *} \\
(0.941)\end{array}$ & $\begin{array}{l}-1.657 \\
(1.244)\end{array}$ & $\begin{array}{c}2.146 \\
(1.311)\end{array}$ \\
\hline Log likelihood $=-500.82$ & Wald $\chi^{2}(95)=$ & 4.33 & $>\mathrm{chi}^{2}=0.00$ & & \\
\hline
\end{tabular}




\subsubsection{Household Characteristics}

Farm size is positively related to the adoption of Returning and Composting and is negatively related to the adoption of Discard and Sale. This result may be explained by the fact that farmers with larger farmland areas will have sufficient surrounding areas to consume a large amount of manure, resulting in a higher possibility of the application of Returning and Composting [42]. This result is in agreement with those obtained by Wu et al. [38] and Ren et al. [43], who stated that scaled farming has created more opportunities for the establishment of eco-agriculture and eco-livestock. The coefficient of farm size on Biogas is insignificant, indicating large farm size cannot promote the application of Biogas. A possible explanation is that as Table 4 shows, Composting and Biogas are substitutes; farmers may substitute Biogas by choosing Composting treatment technology.

Off-farm labor has a significant positive impact on Discard and Sale, while it has a significant negative impact on Returning and Composting. These relationships may partly be explained by the fact that Returning and Composting are labor-intensive technologies demanding a large amount of time and labor input. Households with more off-farm labor will have less labor to adopt Returning and Composting. This finding was also reported by Kassie et al. [14] and Nigussie et al. [44], who showed that households with a higher share of off-farm labor are less likely to adopt labor-intensive technologies.

Unexpectedly, the impact of household income is significant only in the model of Returning, suggesting that household income has no impact on the adoption of SMTTs. This result corroborates the findings of Luo et al. [45], who showed that financial constraint is not the main factor that hinders farmers from adopting sustainable agricultural technologies.

\subsubsection{Pig Breeding Characteristics}

In accordance with our expectation, the pig breeding scale has a significant positive impact on Biogas, Sale, and Composting, while it has a negative impact on Discard and Returning. Similar results were observed in Zheng et al. [41], who found that large-scale farms are more likely to adopt SMTTs. There are three possible explanations for this result. First, with the increase of pig breeding scale, the scale economic benefit of adopting SMTTs is greater, resulting in a higher possibility of adopting SMTTs. Second, large-scale pig breeding farms (market pig inventory of more than 500) are under strict environmental regulation and are required to adopt SMTTs by government. For instance, the technology standard "Discharge Standard of Pollution from Livestock Cultivation", issued by the Chinese State Council, set specific regulations for sustainable manure treatment of scaled farms. Third, large-scale pig breeding farms often lack adequate farmland to absorb relatively greater amounts of generated manure, resulting in a lower possibility of Discard and Returning.

The coefficient of the share of pig breeding income is significant only in the model of Returning, which contradicts our expectation. This inconsistency may be due to that households with a higher share of pig breeding income also have more labor engaged in agriculture, thus resulting in a higher likelihood of adopting Returning, which is a labor-intensive technology.

\subsubsection{Environmental Awareness}

In line with previous studies [46-48], environmental awareness is important for explaining the decision to adopt SMTTs. The estimates related to environmental impact awareness of manure show that compared with farmers who consider manure has no negative impact on the environment, farmers who consider manure has a less serious negative impact on the environment have a higher likelihood of adopting Biogas and a lower likelihood of adopting Returning, while farmers who consider manure has a serious negative impact on the environment have a higher likelihood of adopting Biogas and a lower likelihood of adopting Returning and Discard. Compared with farmers who consider manure to have no negative impact on human health, farmers who consider manure to have a less serious negative impact on human health have higher possibilities of adopting Biogas, while farmers who consider 
manure to have a serious negative impact on human health have higher possibilities of adopting Biogas and a lower likelihood of adopting Returning and Discard.

In addition, our results suggest that farmers willing to treat manure have higher possibilities of adopting SMTTs, such as Composting, Biogas, and Sale, and are less likely to adopt unsustainable manure treatment technologies, such as Returning and Discard.

\subsubsection{Government Support Policies}

The coefficient for biogas subsidy is not significant in any of the five models, indicating that biogas subsidy has no impact on the adoption of SMTTs. This result contradicts with our expectation but it is similar to the previous study of Sun et al. [49], showing that the net effect of biogas subsidy on household biogas development was almost negligible. Three possible explanations are as follows. First, compared with the actual investment in SMTTs, the biogas subsidy is relatively low, resulting in a low incentive for farmers to adopt SMTTs. For example, the current level of biogas subsidy is 500 RMB for each household biogas digester in northeastern and western areas of China, 1200 RMB in central areas of China, and 1000 RMB in eastern areas of China [50]. The average cost of a household biogas digester is approximately $2000 \mathrm{RMB}$. As a result, approximately $50 \%$ of the biogas digester construction cost should be paid by farmers, which hinders the installation of biogas digesters [10]. Second, the biogas subsidy is not targeted effectively. The current biogas subsidy mainly targeted household biogas projects. However, because of the great transformation of the agricultural and rural social environment and other factors, such as scaled livestock breeding, agricultural modernization, and off-farm activities, the impact of biogas subsidy on the development of household biogas projects has been weakened [51]. Third, the economic profit of the household biogas project is very weak, which worsens the impact of biogas subsidy on SMTTs' adoption. It is estimated that the annual economic benefit of a household biogas digester, including profits from biogas power generation and fertilizer sale, is only $1300 \mathrm{RMB}$ when subsidy provided and negative when no subsidy provided [10].

However, our results show that composting subsidy can promote the adoption of Composting. This is because composting subsidy in rural China has flexible ways to subsidize composting production, which can reduce the three main costs for the adoption of Composting, namely high production cost, high transportation cost, and expensive composted fertilizer price [3]. First, composting subsidy can subsidize composting equipment, such as manure beds, perforated tubes, blowers, forklifts, and heap turners, which helps to decrease the production cost of compost fertilizer [52]. It can also subsidize the transportation of composting fertilizer to lower the high transportation cost. Meanwhile, composting subsidy can provide financial supports to encourage farmers to replace composting fertilizer for inorganic fertilizer. In some programs, the level of subsidy for composting fertilizer is about $180-450 \mathrm{RMB} /$ ton in rural China, which is equal to $20 \%$ of the total price of composting fertilizers [7].

The technical training variable is negatively related to the adoption of Discard, indicating that trained farmers are less likely to adopt Discard. However, unexpectedly, the coefficient for technical training was not significant in the models of Composting and Biogas, suggesting that technical training has no impact on the adoption of SMTTs. A possible reason is that the central objective of the Chinese livestock technical training system is to maximize livestock production to meet the growing consumption demand for a long time. Livestock technical training systems in China generally only extend yield-increasing technologies and neglect environmental-protection technologies [53]. As a result, almost $80 \%$ of the pig farmers in our sample do not have experience attending any technical training programs on the adoption of SMTTs. Therefore, it is not surprising that technical training has not increased the adoption of SMTTs.

\subsection{Robustness Check: Addressing the Endogeneity Problem}

There may be a potential endogeneity problem in the MVP model because some explanatory variables could be endogenous. For example, manure treatment willingness is one of endogenous variables. First, there may be a reverse effect between manure treatment willingness and adoption of manure treatment technologies. For instance, farmers who have adopted SMTTs will know the benefits 
and constraints of new technologies better and will thus have higher willingness to treat manure. Second, both manure treatment willingness and adoption of manure treatment technologies may be affected by some omitted variables. For example, some unobservable household characteristics, such as motivation, ability, or breeding skill, may influence the adoption decision of manure treatment technologies, and they also may be correlated to farmers' manure treatment willingness.

To address the endogeneity problem, according to the suggestion by Kassie et al. [54], we conducted the MVP model without the potentially endogenous variable (manure treatment willingness in our case). The results are presented in Table 6 . A comparison of the coefficients associated with the variables in Tables 5 and 6 shows that most of the estimated coefficients are almost the same. This finding supports the robustness of our results when considering the endogeneity problem.

Table 6. Estimates of the multivariate probit model excluding potential endogenous variable.

\begin{tabular}{|c|c|c|c|c|c|}
\hline Variables & Discard & Returning & Biogas & Sale & Composting \\
\hline \multicolumn{6}{|l|}{ Individual characteristics } \\
\hline Age & $\begin{array}{l}0.035^{* *} \\
(0.015)\end{array}$ & $\begin{array}{c}0.016 \\
(0.012)\end{array}$ & $\begin{array}{l}-0.010 \\
(0.008)\end{array}$ & $\begin{array}{l}-0.021 \\
(0.014)\end{array}$ & $\begin{array}{l}-0.007 \\
(0.014)\end{array}$ \\
\hline Education & $\begin{array}{c}-0.024 * \\
(0.013)\end{array}$ & $\begin{array}{l}-0.032^{* *} \\
(0.014)\end{array}$ & $\begin{array}{l}0.022 * \\
(0.011)\end{array}$ & $\begin{array}{l}0.02 * * \\
(0.009)\end{array}$ & $\begin{array}{c}0.023 \\
(0.143)\end{array}$ \\
\hline Leader & $\begin{array}{l}-0.215 \\
(0.143)\end{array}$ & $\begin{array}{l}-0.232 \\
(0.266)\end{array}$ & $\begin{array}{c}0.132 \\
(0.098)\end{array}$ & $\begin{array}{l}0.165^{* *} \\
(0.063)\end{array}$ & $\begin{array}{l}-0.302 \\
(0.244)\end{array}$ \\
\hline Breeding experience & $\begin{array}{c}0.013 \\
(0.017)\end{array}$ & $\begin{array}{c}0.015 \\
(0.031)\end{array}$ & $\begin{array}{l}-0.026 \\
(0.018)\end{array}$ & $\begin{array}{c}0.018 \\
(0.022)\end{array}$ & $\begin{array}{l}-0.015 \\
(0.022)\end{array}$ \\
\hline \multicolumn{6}{|c|}{ Risk attitude (Risk-adverse farmers as reference) } \\
\hline \multirow{2}{*}{$\begin{array}{l}\text { Risk-loving farmers } \\
\text { Risk-neutral farmers }\end{array}$} & $\begin{array}{l}-0.147 \\
(0.168)\end{array}$ & $\begin{array}{l}-0.215 \\
(0.166)\end{array}$ & $\begin{array}{l}0.075^{* *} \\
(0.032)\end{array}$ & $\begin{array}{c}0.055 \\
(0.129)\end{array}$ & $\begin{array}{l}0.074^{* * *} \\
(0.031)\end{array}$ \\
\hline & $\begin{array}{l}-0.151 \\
(0.116)\end{array}$ & $\begin{array}{l}-0.044 \\
(0.142)\end{array}$ & $\begin{array}{l}-0.065 \\
(0.177)\end{array}$ & $\begin{array}{l}-0.432 \\
(0.268)\end{array}$ & $\begin{array}{c}0.153 \\
(0.177)\end{array}$ \\
\hline \multicolumn{6}{|l|}{ Household characteristics } \\
\hline Farm size & $\begin{array}{l}-0.016^{* *} \\
(0.008)\end{array}$ & $\begin{array}{l}0.019^{* * *} \\
(0.007)\end{array}$ & $\begin{array}{l}-0.013 \\
(0.034)\end{array}$ & $\begin{array}{l}-0.021 \\
(0.014)\end{array}$ & $\begin{array}{c}0.017^{* * *} \\
(0.006)\end{array}$ \\
\hline Share of off-farm labor & $\begin{array}{l}0.028 * \\
(0.014)\end{array}$ & $\begin{array}{l}-0.036^{* * *} \\
(0.013)\end{array}$ & $\begin{array}{c}0.045 \\
(0.036)\end{array}$ & $\begin{array}{l}0.031 * * * \\
(0.0114)\end{array}$ & $\begin{array}{l}-0.043 * * \\
(0.019)\end{array}$ \\
\hline Household income & $\begin{array}{c}0.000 \\
(0.000) \\
\end{array}$ & $\begin{array}{l}-0.003 \\
(0.003) \\
\end{array}$ & $\begin{array}{c}0.000 \\
(0.000) \\
\end{array}$ & $\begin{array}{l}-0.002 \\
(0.001)\end{array}$ & $\begin{array}{c}0.000 \\
(0.000)\end{array}$ \\
\hline \multicolumn{6}{|l|}{ Pig breeding characteristics } \\
\hline \multirow{2}{*}{$\begin{array}{l}\text { Pig breeding scale } \\
\text { Share of pig breeding income }\end{array}$} & $\begin{array}{l}-0.003 * * \\
(0.001)\end{array}$ & $\begin{array}{l}-0.005^{* *} \\
(0.002)\end{array}$ & $\begin{array}{l}0.003^{* * *} \\
(0.001)\end{array}$ & $\begin{array}{l}0.002^{* *} \\
(0.001)\end{array}$ & $\begin{array}{l}0.003^{* *} \\
(0.001)\end{array}$ \\
\hline & $\begin{array}{c}0.032 \\
(0.022) \\
\end{array}$ & $\begin{array}{c}0.028^{* *} \\
(0.012)\end{array}$ & $\begin{array}{l}-0.026 \\
(0.024)\end{array}$ & $\begin{array}{c}0.065 \\
(0.064) \\
\end{array}$ & $\begin{array}{l}-0.016 \\
(0.017)\end{array}$ \\
\hline \multicolumn{6}{|l|}{ Environmental awareness } \\
\hline \multicolumn{6}{|c|}{ Environmental impact awareness of manure (nearly no negative impact as reference) } \\
\hline Little negative impact & $\begin{array}{c}0.165 \\
(0.124)\end{array}$ & $\begin{array}{l}-0.209 \\
(0.166)\end{array}$ & $\begin{array}{c}0.224 \\
(0.168)\end{array}$ & $\begin{array}{l}-0.255 \\
(0.176)\end{array}$ & $\begin{array}{c}0.047 \\
(0.142)\end{array}$ \\
\hline Less serious negative impact & $\begin{array}{l}-0.244 \\
(0.165)\end{array}$ & $\begin{array}{l}-0.304 \\
(0.187)\end{array}$ & $\begin{array}{c}0.568^{* * *} \\
(0.163)\end{array}$ & $\begin{array}{c}0.322 \\
(0.218)\end{array}$ & $\begin{array}{c}0.121 \\
(0.134)\end{array}$ \\
\hline Serious negative impact & $\begin{array}{c}-0.073^{* *} \\
(0.035)\end{array}$ & $\begin{array}{l}-0.693^{* * *} \\
(0.201)\end{array}$ & $\begin{array}{c}0.987^{* * *} \\
(0.197)\end{array}$ & $\begin{array}{l}-0.458 \\
(0.292)\end{array}$ & $\begin{array}{c}0.187 \\
(0.215)\end{array}$ \\
\hline \multicolumn{6}{|c|}{ Human health impact awareness of manure(nearly no negative impact as reference) } \\
\hline Little negative impact & $\begin{array}{c}0.215 \\
(0.168)\end{array}$ & $\begin{array}{l}-0.022 \\
(0.172)\end{array}$ & $\begin{array}{c}0.033 \\
(0.156)\end{array}$ & $\begin{array}{l}-0.248 \\
(0.175)\end{array}$ & $\begin{array}{l}-0.143 \\
(0.121)\end{array}$ \\
\hline Less serious negative impact & $\begin{array}{l}-0.212 \\
(0.198)\end{array}$ & $\begin{array}{c}0.246 \\
(0.153)\end{array}$ & $\begin{array}{l}0.302 * * \\
(0.142)\end{array}$ & $\begin{array}{l}-0.215 \\
(0.290)\end{array}$ & $\begin{array}{l}-0.694 \\
(0.432)\end{array}$ \\
\hline Serious negative impact & $\begin{array}{l}-0.147^{*} \\
(0.083)\end{array}$ & $\begin{array}{l}-0.303^{* *} \\
(0.146)\end{array}$ & $\begin{array}{l}0.169 * * * \\
(0.063)\end{array}$ & $\begin{array}{c}0.206 \\
(0.132)\end{array}$ & $\begin{array}{c}0.766 \\
(0.642)\end{array}$ \\
\hline
\end{tabular}


Table 6. Cont.

\begin{tabular}{lccccc}
\hline Variables & Discard & Returning & Biogas & Sale & Composting \\
\hline Government support policies & \multicolumn{7}{c}{} & & & \\
\hline \multirow{2}{*}{ Biogas subsidy } & -0.023 & -0.014 & 0.043 & -0.024 & 0.098 \\
& $(0.132)$ & $(0.036)$ & $(0.064)$ & $(0.098)$ & $(0.114)$ \\
Composting subsidy & -0.068 & -0.032 & 0.025 & 0.076 & $0.034^{* *}$ \\
& $(0.131)$ & $(0.082)$ & $(0.074)$ & $(0.113)$ & $(0.014)$ \\
Technical training & $-0.213^{* *}$ & -0.068 & 0.065 & 0.094 & 0.321 \\
& $(0.087)$ & $(0.126)$ & $(0.076)$ & $(0.115)$ & $(0.243)$ \\
Constant & $-4.319 * *$ & $3.345^{* * *}$ & $4.327 * *$ & $-1.657^{* * *}$ & $3.143^{* *}$ \\
& $(1.452)$ & $(0.862)$ & $(0.941)$ & $(0.344)$ & $(1.311)$ \\
\hline Log likelihood $=-654.38$ & Wald $\chi^{2}(95)=323.96 \quad$ Prob $>$ chi $^{2}=0.000$ & &
\end{tabular}

Note: (1) Robust standard errors within brackets. (2) ${ }^{* * *}, * * *$ denote statistical significance at the one percent, five percent, and ten percent levels, respectively.

\section{Conclusions}

A significant challenge facing the Chinese government is to manage massive amounts of manure in a sustainable way to reduce environmental pollution, alleviate the energy shortage, and decrease inorganic fertilizer use. Understanding farmers' adoption behavior of SMTTs is an essential prerequisite for an efficient policy design of sustainable livestock production. Based on a large household data survey in Poyang Lake Region in rural China, this study investigated the factors that influence farmers' adoption decisions of multiple types of SMTTs in pig production in rural China using a multivariate probit model.

We found that the adoption rates of SMTTs are very low. Only $58 \%$ of the pig farmers have adopted SMTTs for Biogas, Composting, and Sale, suggesting a great potential to enhance the adoption rates of SMTTs to safeguard environmental sustainability. Our results also show that many manure treatment technologies are related to each other, some complementary, and others substitutable. Hence, policies aimed at promoting the adoption of SMTTs should consider technology interdependence.

Our results indicate that the adoption of SMTTs requires sufficient labor input. Households with a higher share of off-farm labor are less likely to adopt SMTTs. This suggests that if China wants to achieve broad-based adoption of SMTTs among farmers, policies must fully account for the impact of off-farm activities on labor availability and time devoted to the adoption of SMTTs.

Our results also confirm that the adoption of SMTTs requires adequate knowledge. Farmers with higher environmental awareness are more likely to adopt SMTTs. Hence, improving environmental awareness is a primary channel to promote the adoption of SMTTs. However, the environmental awareness of pig farmers in our sample is relatively low. Most pig farmers identified that manure has "nearly no" or "little" impact on the environment and human health. There is significant potential to increase farmers' environmental awareness and enhance the adoption of SMTTs.

Furthermore, our results show that government support policies, such as biogas subsidy and technical training, have no impact on farmers' adoption of SMTTs. This is mainly due to the inappropriateness and low efficiency of biogas subsidy and insufficient technical training. However, the subsidy encourages the adoption of composting. Therefore, designing scientific biogas subsidy, such as shifting the biogas subsidy from the construction stage to the follow-up management stage, and providing more technical training programs for the sustainable treatment of manure are steps that might improve the adoption of SMTTs.

Author Contributions: Conceptualization, J.C. and D.P.; data curation, J.C. and J.T.; formal analysis, J.C. and L.Z.; funding acquisition, L.Z. and D.P.; investigation, J.T.; methodology, J.T. and D.P.; project administration, J.C., L.Z., and D.P.; software, J.T. and D.P.; writing-original draft, J.C. and D.P.; writing—review and editing, L.Z. and D.P.

Funding: We would like to thank the financial support from the National Youth Talent Support Program, the National Natural Science Foundation of China (No. 71863016; No. 71673123; No. 71663025), the Outstanding Youth of Natural Science Foundation in Jiangxi Province (No. 2018ACB21004), the Science and Technology 
Research Foundation of Jiangxi Province (No. GJJ170349), and the Postgraduate Innovation Research Foundation of Jiangxi Province (No. YC2019-S210).

Conflicts of Interest: The authors declare no conflict of interest.

\section{References}

1. Bai, Z.; Ma, W.; Ma, L.; Velthof, G.L.; Wei, Z.; Havlík, P.; Oenema, O.; Lee, M.R.F.; Zhang, F. China's livestock transition: Driving forces, impacts, and consequences. Sci. Adv. 2018, 4, eaar8534. [CrossRef] [PubMed]

2. Zhang, C.; Liu, S.; Wu, S.; Jin, S.; Reis, S.; Liu, H.; Gu, B. Rebuilding the linkage between livestock and cropland to mitigate agricultural pollution in China. Resour. Conserv. Recycl. 2019, 144, 65-73. [CrossRef]

3. Chadwick, D.; Jia, W.; Tong, Y.; Yu, G.; Shen, Q.; Chen, Q. Improving manure nutrient management towards sustainable agricultural intensification in China. Agric. Ecosyst. Environ. 2015, 209, 34-36. [CrossRef]

4. Ma, L.; Bai, Z.; Ma, W.; Guo, M.; Jiang, R.; Liu, J.; Oenema, O.; Velthof, G.L.; Whitmore, A.P.; Crawford, J.; et al. Exploring Future Food Provision Scenarios for China. Environ. Sci. Technol. 2019, 53, 1385-1393. [CrossRef] [PubMed]

5. Pan, D. The Design of Policy Instruments towards Sustainable Livestock Production in China: An Application of the Choice Experiment Method. Sustainability 2016, 8, 611. [CrossRef]

6. De Clercq, D.; Wen, Z.; Caicedo, L.; Cao, X.; Fan, F.; Xu, R. Application of DEA and statistical inference to model the determinants of biomethane production efficiency: A case study in south China. Appl. Energy 2017, 205, 1231-1243. [CrossRef]

7. Pan, D.; Zhou, G.; Zhang, N.; Zhang, L. Farmers' preferences for livestock pollution control policy in China: A choice experiment method. J. Clean. Prod. 2016, 131, 572-582. [CrossRef]

8. Zhuang, M.; Lu, X.; Caro, D.; Gao, J.; Zhang, J.; Cullen, B.; Li, Q. Emissions of non-CO 2 greenhouse gases from livestock in China during 2000-2015: Magnitude, trends and spatiotemporal patterns. J. Environ. Manag. 2019, 242, 40-45. [CrossRef]

9. Bluemling, B.; Wang, F. An institutional approach to manure recycling: Conduit brokerage in Sichuan Province, China. Resour. Conserv. Recycl. 2018, 139, 396-406. [CrossRef]

10. Wang, C.; Zhang, Y.; Zhang, L.; Pang, M. Alternative policies to subsidize rural household biogas digesters. Energy Policy 2016, 93, 187-195. [CrossRef]

11. Yin, D.; Liu, W.; Zhai, N.; Wang, Y.; Ren, C.; Yang, G. Regional differentiation of rural household biogas development and related driving factors in China. Renew. Sustain. Energy Rev. 2017, 67, 1008-1018. [CrossRef]

12. Yan, Z.; Wang, C.; Xu, J.; Huo, X.; Hussain, Q. Examining the effect of absorptive capacity on waste processing method adoption: A case study on Chinese pig farms. J. Clean. Prod. 2019, 215, 978-984. [CrossRef]

13. Huang, W.; Qiao, F.; Liu, H.; Jia, X.; Lohmar, B. From backyard to commercial hog production: Does it lead to a better or worse rural environment? China Agric. Econ. Rev. 2016, 8, 22-36. [CrossRef]

14. Kassie, M.; Jaleta, M.; Shiferaw, B.; Mmbando, F.; Mekuria, M. Adoption of interrelated sustainable agricultural practices in smallholder systems: Evidence from rural Tanzania. Technol. Forecast. Soc. Chang. 2013, 80, 525-540. [CrossRef]

15. Zheng, C.; Liu, Y.; Bluemling, B.; Mol, A.P.; Chen, J. Environmental potentials of policy instruments to mitigate nutrient emissions in Chinese livestock production. Sci. Total Environ. 2015, 502, 149-156. [CrossRef] [PubMed]

16. Liu, G.; Luo, Q.; Zhang, L. The Development of Animal Husbandry Since 40 Years of Reform and Opening-up: Achievements, Challenges and Countermeasures. China Rural Econ. 2018, 12, 19-36. (In Chinese)

17. Kung, C.; Kong, F.; Choi, Y. Pyrolysis and biochar potential using crop residues and agricultural wastes in China. Ecol. Indic. 2015, 51, 139-145. [CrossRef]

18. Fan, X.; Liu, Y.; Tao, J.; Wang, Y.; Zhou, H. MODIS detection of vegetation changes and investigation of causal factors in Poyang Lake basin, China for 2001-2015. Ecol. Indic. 2018, 91, 511-522. [CrossRef]

19. Brown, P.; Daigneault, A.; Dawson, J. Age, values, farming objectives, past management decisions, and future intentions in New Zealand agriculture. J. Environ. Manag. 2019, 231, 110-120. [CrossRef]

20. Daxini, A.; Ryan, M.; Donoghue, C.O.; Barnes, A.P. Understanding farmers' intentions to follow a nutrient management plan using the theory of planned behaviour. Land Use Policy 2019, 85, 428-437. [CrossRef] 
21. Miyashita, K.; Nishimura, S.; Toyofuku, T.; Shirakashi, J.I. Personal circumstances and social characteristics as determinants of landholder participation in biodiversity conservation programs. J. Environ. Manag. 2012, 113, 292-300.

22. Yao, Y.X.Y. Informal Institutions, Collective Action, and Public Investment in Rural China. Am. Polit. Sci. Rev. 2015, 109, 371-379.

23. Doris, L. Adoption and Abandonment of Organic Farming: An Empirical Investigation of the Irish Drystock Sector. J. Agric. Econ. 2010, 61, 697-714.

24. Läpple, D.; Kelley, H. Spatial dependence in the adoption of organic drystock farming in Ireland. Eur. Rev. Agric. Econ. 2015, 42, 315-337. [CrossRef]

25. Gedikoglu, H.; McCann, L.; Artz, G. Off-farm employment effects on adoption of nutrient management practices. Agric. Resour. Econ. Rev. 2011, 40, 293-306. [CrossRef]

26. Manda, J.; Alene, A.D.; Gardebroek, C.; Kassie, M.; Gelson, T. Adoption and Impacts of Sustainable Agricultural Practices on Maize Yields and Incomes: Evidence from Rural Zambia. J. Agric. Econ. 2016, 67, 891-896. [CrossRef]

27. Birhanu, M.Y.; Girma, A.; Puskur, R. Determinants of success and intensity of livestock feed technologies use in Ethiopia: Evidence from a positive deviance perspective. Technol. Forecast. Soc. 2016, 115, 15-25. [CrossRef]

28. Hu, Y.; Li, B.; Zhang, Z.; Wang, J. Farm size and agricultural technology progress: Evidence from China. J. Rural Stud. 2019, in press. [CrossRef]

29. Pan, D.; Yang, J.; Guo, Q.; Lu, Q.; Zhang, N. Toward better environmental performance in hog production in China: Is intensification the answer? Ecol. Indic. 2019, 105, 347-354. [CrossRef]

30. Ajzen, I. From Intentions to Actions: A Theory of Planned Behavior; Springer: Berlin/Heidelberg, Germany, 1985; pp. 1-63.

31. Baumgart-Getz, A.; Prokopy, L.S.; Floress, K. Why farmers adopt best management practice in the United States: A meta-analysis of the adoption literature. J. Environ. Manag. 2012, 96, 17-25. [CrossRef]

32. Schneider, M. Wasting the rural: Meat, manure, and the politics of agro-industrialization in contemporary China. Geoforum 2017, 78, 89-97. [CrossRef]

33. Tang, J.; Folmer, H.; Xue, J. Adoption of farm-based irrigation water-saving techniques in the Guanzhong Plain, China. Agric. Econ. 2016, 47, 445-455. [CrossRef]

34. Dorfman, J.H. Modeling Multiple Adoption Decisions in a Joint Framework. Am. J. Agric. Econ. 1996, 78, 547-557. [CrossRef]

35. Greene, W.H. Econometric Analysis; Prentice Hall: New York, NY, USA, 2003.

36. Rodríguez-Entrena, M.; Arriaza, M. Adoption of conservation agriculture in olive groves: Evidences from southern Spain. Land Use Policy 2013, 34, 294-300. [CrossRef]

37. Cappellari, L.; Jenkins, S.P. Multivariate probit regression using simulated maximum likelihood. Stata J. 2003, 3, 278-294. [CrossRef]

38. Wu, Y.; Xi, X.; Tang, X.; Luo, D.; Gu, B.; Lam, S.K.; Vitousek, P.M.; Chen, D. Policy distortions, farm size, and the overuse of agricultural chemicals in China. Proc. Natl. Acad. Sci. USA 2018, 115, 7010-7015. [CrossRef]

39. Jiao, X.; Mongol, N.; Zhang, F. The transformation of agriculture in China: Looking back and looking forward. J. Integr. Agric. 2018, 17, 755-764. [CrossRef]

40. Wei, S.; Bai, Z.H.; Qin, W.; Xia, L.J.; Oenema, O.; Jiang, R.F.; Ma, L. Environmental, economic and social analysis of peri-urban pig production. J. Clean. Prod. 2016, 129, 596-607. [CrossRef]

41. Zheng, C.; Bluemling, B.; Liu, Y.; Mol, A.P.; Chen, J. Managing Manure from China's Pigs and Poultry: The Influence of Ecological Rationality. Ambio 2014, 43, 661-672. [CrossRef]

42. Smith, L.; Siciliano, G. A comprehensive review of constraints to improved management of fertilizers in China and mitigation of diffuse water pollution from agriculture. Agric. Ecosyst. Environ. 2015, 209, $15-25$. [CrossRef]

43. Ren, C.; Liu, S.; Liu, H.; van Grinsven, H.; Reis, S.; Jin, S.; Gu, B. The impact of farm size on agricultural sustainability. J. Clean. Prod. 2019, 220, 357-367. [CrossRef]

44. Nigussie, A.; Kuyper, T.W.; de Neergaard, A. Agricultural waste utilisation strategies and demand for urban waste compost: Evidence from smallholder farmers in Ethiopia. Waste Manag. 2015, 44, 82-93. [CrossRef] [PubMed] 
45. Luo, X.; Feng, S.; Liu, H.; Zhao, B. Large-Scale grain producers' application of land conservation technologies in China: correlation effects and determinants. Sustainability 2019, 11, 441. [CrossRef]

46. Gachango, F.G.; Andersen, L.M.; Pedersen, S.M. Adoption of voluntary water-pollution reduction technologies and water quality perception among Danish farmers. Agric. Water Manag. 2015, 158, 235-244. [CrossRef]

47. Tang, J.; Folmer, H.; Xue, J. Estimation of awareness and perception of water scarcity among farmers in the Guanzhong Plain, China, by means of a structural equation model. J. Environ. Manag. 2013, 126, 55-62. [CrossRef] [PubMed]

48. Obubuafo, J.; Gillespie, J.M.; Paudel, K.P.; Kim, S. Awareness of and Application to the Environmental Quality Incentives Program. J. Agric. Appl. Econ. 2011, 40, 357-368. [CrossRef]

49. Sun, D.; Bai, J.; Qiu, H.; Cai, Y. Impact of government subsidies on household biogas use in rural China. Energy Policy 2014, 73, 748-756. [CrossRef]

50. Song, Z.; Zhang, C.; Yang, G.; Feng, Y.; Ren, G.; Han, X. Comparison of biogas development from households and medium and large-scale biogas plants in rural China. Renew. Sustain. Energy Rev. 2014, 33, $204-213$. [CrossRef]

51. Wang, X.J.; Lu, X.G.; Yang, G.H.; Feng, Y.Z.; Ren, G.X.; Han, X.H. Development process and probable future transformations of rural biogas in China. Renew. Sustain. Energy Rev. 2016, 55, 703-712. [CrossRef]

52. Qian, Y.; Song, K.; Hu, T.; Ying, T. Environmental status of livestock and poultry sectors in China under current transformation stage. Sci. Total Environ. 2018, 622, 702-709. [CrossRef]

53. Hu, R.; Cao, J.; Huang, J.; Peng, S.; Huang, J.; Zhong, X.; Zou, Y.; Yang, J.; Buresh, R.J. Farmer participatory testing of standard and modified site-specific nitrogen management for irrigated rice in China. Agric. Syst. 2007, 94, 331-340. [CrossRef]

54. Kassie, M.; Teklewold, H.; Jaleta, M.; Marenya, P.; Erenstein, O. Understanding the adoption of a portfolio of sustainable intensification practices in eastern and southern Africa. Land Use Policy 2015, 42, 400-411. [CrossRef]

(C) 2019 by the authors. Licensee MDPI, Basel, Switzerland. This article is an open access article distributed under the terms and conditions of the Creative Commons Attribution (CC BY) license (http://creativecommons.org/licenses/by/4.0/). 